\section{Western Sudan Arabi camel hides attributes and leather quality characteristics}

\section{Mohammed Alhadi Ebrahiem* and Idris Adam Idris}

Department of Animal Production, Faculty of Natural Resources and Environmental Studies, University of Kordofan, Sudan
Received: 20 October, 2021

Accepted: 24 November, 2021

Published: 02 December, 2021

*Corresponding author: Mohammed Alhadi Ebrahiem, Department of Animal Production, Faculty of Natural Resources and Environmental Studies, University of Kordofan, Sudan, Email: mahaali5656@gmail.com

ORCID: https://orcid.org/0000-0003-545-1242

Keywords: Western Sudan; Arabi camel; Camel hides attributes; Leather quality

Copyright: (c) 2021 Ebrahiem MA, et al. This is an open-access article distributed under the terms of the Creative Commons Attribution License, which permits unrestricted use, distribution, and reproduction in any medium, provided the original author and source are credited.

https://www.peertechzpublications.com

\title{
Abstract
}

This study was aimed to evaluate camel hide attributes and leather quality characteristics of Western Sudan Arabi camel. Thirty pieces of fresh camel hides from three subtypes of Western Sudan Arabi camel ecotype (10 pieces from each of Kababish, Meidob, and Hawawir subtypes) were collected, cured, and tanned. Physical and chemical quality parameters were assessed. The data were analyzed using the Complete Randomized Block design. The results revealed that Significant differences $(P \leq 0.05)$ were detected among Western Sudan Arabi camel subtypes fresh hides thickness and weight. Kababish hide thickness and weight were recorded the highest value of $0.155 \pm 0.4 \mathrm{~cm}$ and $11.7 \pm 1.3 \mathrm{Kg}$ respectively in comparison to Meidob $(0.145 \pm 0.3 \mathrm{~cm}$ and $8.6 \pm 1.2 \mathrm{Kg})$ and $\mathrm{Hawawir}(0.143 \pm 0.4 \mathrm{~cm}$ and $7.7 \pm 2.2 \mathrm{Kg})$. Kababish hides thickness value was above the minimum Sudanese standard threshold specification for cattle leather quality. While Meidob and Hawawir hide thickness values were blew the minimum Sudanese standard threshold specification for cattle leather quality. Physical quality parameters; elongation, tensile strength, resistance to grain cracking, breaking load, and tear strength; were in the Sudanese standard threshold specification for cattle leather physical quality of $100 \%, 200 \mathrm{Kg} / \mathrm{cm}^{2}, 7 \mathrm{~N} / \mathrm{cm}, 8 \mathrm{~N} / \mathrm{cm}$, and $100 \mathrm{Kg} / \mathrm{cm}^{2}$ respectively. Whilst flexibility parameter was below the Sudanese standard threshold specification for cattle leather quality. Chemical quality parameters were in the Sudanese standards threshold specification for cattle leather chemical quality of $18 \%, 4.5 \%, 2.5 \%$, and $11 \%$ for moisture, Ash, chrome oxide, and fat contents respectively.

\section{Introduction}

Camels constitute $22 \%$ of the animal census in Sudan and $26.3 \%$ of the camel population in the Arab world. The estimation of the camel's population in Sudan was about 3,908 thousand heads [1]. These camels are spread in a belt that extends between latitudes $12-16 \mathrm{~N}$ [2]. Since their domestication, camels have played a vital role in the daily life of many societies, where other livestock farming operations cannot be easily practiced [3]. Camels provide humans with a range of products and services, from fine wool to meat, milk, and draught power. Camels have the ability to go for long periods without water and live on thorny and high fiber diets, stand high altitudes, and extreme temperatures, making them one of the few families well adapted for food and agricultural production under harsh semi-desert environments $[2,4]$.
Camels in Sudan and elsewhere are classified as a pack (heavy) and riding (light) types according to their function. Recent studies had been made to classify the camels according to their performance like dairy camels, meat camels, dualpurpose camels, and racing camels [1,5]. The Arabi Type is a heavy type that makes up the majority of the camel maintained by nomads about $80 \%$ [6]. They are sub-grouped into Arabi types and Rashaidi (Sawahli) types.

The Arabi type found in Kordufan, Darfur, and the Blue Nile constitute about $96 \%$, and in eastern Sudan, it is about $55 \%$ of the total in that area. Most of the Sudanese camels are large heavy massive types with slow mobility [6]. Mainly the Arabi type is described as a large heavily built animal with a welldeveloped hump, and it has short hair except in the shoulder and hump. The mature camel weighs about $400-500 \mathrm{~kg}$ as a 
life weight, and can carry about $275 \mathrm{Kg}$ over 25 -30km per day, and is sandy gray. In western Sudan, the Meidob and Hawawir have herds of comparatively lightweight camels; some of which can be ridden [7].

\section{Materials and methods}

\section{The study area}

Kordofan region is located between latitudes $9^{\circ}: 30^{-}-16^{\circ}: 30^{-}$ North and longitudes $24^{\circ}-32^{\circ}: 25^{-}$East. The region consists of North, West, and South states forming a total area of 380,000 $\mathrm{Km}^{2}$ (90 million feddan). Each of the three states existed independently of one another while subscribing to the authority and jurisdiction of the federal government [8].

\section{Selection of experiment camel hides}

Thirty (30) pieces of fresh camel hide from three (3) Arabi camels'subtypes (10 pieces from each of Kababish, Meidob, and Hawawir subtypes)which bring from different geographical areas from West Sudan (Kordofan Rejoin).

\section{Tanning procedures}

Leather was prepared from camel hides according to the following main steps: Soaking, Liming, Deliming, Bating, Pickling, Tanning, Neutralization, and Re-tanning (Table 1). Sampling and assessment of chemical and physical characteristics were done according to SSMO (Sudanese Standard and Meteorology Organization) methodology. Physical properties that were assessed are: Tensile strength and elongation\% according to [9], Flexibility test according to [10] and Measurement of tearing load and resistance to grain cracking according to [11]. Whilst, chemical characteristics were: moisture\% according to [12], total Ash\% According to SSMO2 (2006), fats and oils\% according to [13], and chromium $\%$ according to [14] procedures.

\section{Statistical analysis}

The data were statistically analyzed according to Complete Randomized Block Design using SPSSv.14.0 software package [15]. LSD test was used for means separation, besides comparing skin and leather measurements results with Sudanese Standard thresholds for leather quality according to SSMO standards.

\section{Results and discussion}

\section{Western Sudan Arabi camel fresh hides attributes}

Significant differences $(\mathrm{P} \leq 0.05)$ were detected among Western Sudan Arabi camel subtypes fresh hides thickness. Kababish subtype of Western Sudan Arabi camel was scored the highest value of $0.155 \pm 0.4 \mathrm{~cm}$ in comparison to $0.145 \pm 0.3 \mathrm{~cm}$ and $0.143 \pm 0.4 \mathrm{~cm}$ for Meidob and Hawawir subtypes respectively (Table 2). Kababish subtype hide thickness value was above the minimum Sudanese standard threshold specification for cattle leather quality. While Meidob and Hawawir Arabi camel subtypes their hide thickness values were blown the minimum Sudanese standard threshold for cattle leather
Table 1: Experiment tanning procedures.

\begin{tabular}{|c|c|c|c|c|}
\hline Process & Water \% & Chemical material & Chemical \% & Time \\
\hline Socking & 300 & Common water & & $14-16 \mathrm{hrs}$ \\
\hline \multirow[t]{2}{*}{ Unhairing } & 100 & Sodium Sulfide & 2 & $90 \mathrm{~min}$ \\
\hline & & Sodium Sulfide & 2 & $90 \mathrm{~min}$ \\
\hline Liming & 80 & Calcium hydroxide & 3.5 & $12 \mathrm{hrs}$ \\
\hline \multirow[t]{2}{*}{ Deliming } & 100 & Ammonium sulfide & 1 & $1 \mathrm{~h}$ \\
\hline & & Ammonium sulfide & 1 & $1 \mathrm{~h}$ \\
\hline Bating & & Orbon (Zymex-R) & 0.5 & $30 \mathrm{~min}$ \\
\hline Pickling & 80 & Sulfuric acid & 1.5 & $15 \mathrm{~min}$ \\
\hline \multirow[t]{3}{*}{ Tanning } & & Chrome & 3 & $2 \mathrm{hrs}$ \\
\hline & & Chrome & 3 & $2 \mathrm{hrs}$ \\
\hline & & Chrome & 1 & $2 \mathrm{hrs}$ \\
\hline Neutralization & 100 & Sodium by carbonate & 1.5 & $30 \mathrm{~min}$ \\
\hline \multirow[t]{4}{*}{ Retanning } & & Chrome sulfate & 1 & $1 \mathrm{~h}$ \\
\hline & & Sodium by carbonate & 1 & $30 \mathrm{~min}$ \\
\hline & & Fat & 6 & $1 \mathrm{~h}$ \\
\hline & & Mimosa & 6 & $1 \mathrm{~h}$ \\
\hline
\end{tabular}

Table 2: Western Sudan Arabi camel fresh hides attributes.

\begin{tabular}{|c|c|c|c|c|}
\hline Attribute & Kababish & Meidob & Hawawir & Standard \\
\hline Thickness/cm & $0.155 \pm 0.4^{\mathrm{a}}$ & $0.145 \pm 0.3^{\mathrm{b}}$ & $0.143 \pm 0.4^{\mathrm{b}}$ & Minimum $0.150 \mathrm{~cm}$ \\
\hline Weight/Kg & $11.7 \pm 1.3^{\mathrm{a}}$ & $8.6 \pm 1.2^{\mathrm{b}}$ & $7.7 \pm 2.2^{\mathrm{b}}$ & \\
\hline
\end{tabular}

Values in the same row with the same superscripts do not significantly differ at 0.05

quality. Generally the thicker the hide is plump and stout. The properties of leather and its uses depend on the characteristic of the fiber bundles such as fullness, disorderliness, compactness, straightness, delineation, boldness, splitting, and separation. Poor nutrition causes an animal to be smaller and the skin or hide to be thinner and to be a poorer substance [8].

Also, Significant differences $(\mathrm{P} \leq 0.05)$ were detected among Western Sudan Arabi camel subtype's fresh hide's weights. Kababish subtype of Western Sudan Arabi camel has scored the highest value of $11.7 \pm 1.3 \mathrm{Kg}$ in comparison to $0.145 \pm 0.3 \mathrm{Kg}$ and $7.7 \pm 2.2 \mathrm{Kg}$ for Meidob and Hawawir subtypes respectively (Table 2). $[16,17]$ stated that the most prominent features of fresh hides and skins (from cattle, and sheep/goats respectively) are their size, pelage, and color. All these are more or less closely related to the breed of the animal. The size (weight) of a hide or skin is closely related to the weight of the animal from which it came, and is typically between 7 and $11 \%$ of the live weight. Accordingly, the hide of a $1,000 \mathrm{~kg}$ bull may be as much as 110 $\mathrm{kg}$ while the skin of small $(25 \mathrm{Kg})$ sheep or goat may be as little as $1.8 \mathrm{~kg}$ (less in the case of a lamb or kidskin). This variation in size has innumerable implications during the course of tanning and will be referred to later.

\section{Western Sudan Arabi camel leather physical quality pa- rameters}

Significant differences $(\mathrm{P} \leq 0.05)$ were detected within the parameters' values of elongation, tensile strength, breaking 
load, and flexibility respectively. The highest elongation $\%$ and tensile strength $\mathrm{Kg} / \mathrm{cm}^{2}$, breaking load $\mathrm{N} / \mathrm{cm}$ and flexibility\% values of $44.73 \pm 2.2 \%, \quad 225 \pm 6.5 \mathrm{Kg} / \mathrm{cm}^{2}, \quad 9.84 \pm 0.55 \mathrm{~N} / \mathrm{cm}$ and $87.20 \pm 3.9 \%$ respectively, were reported for Kababish subtype leather. On the other hand, no significant differences $(\mathrm{P} \geq 0.05)$ were detected among the values of resistance to grain cracking and tear strength parameters respectively. The highest resistance to grain value and tear strength of $6.74 \pm 1.8$ $\mathrm{N} / \mathrm{cm}$ and $95.56 \pm 5.3 \mathrm{Kg} / \mathrm{cm}^{2}$ were reported for Hawawir subtype leather. Elongation, tensile strength, resistance to grain cracking, breaking load, and tear strength parameters were in the Sudanese standard threshold specification for cattle leather quality. These results confirm with [18] who mentioned that camel leather physical quality elongation percentage, tensile strength, resistance to grain cracking and breaking load of $33.85 \pm 10.42 \%, 207.97 \pm 11.32 \mathrm{Kg} / \mathrm{cm}^{2}, 6.35 \pm 0.69 \mathrm{Kg} / \mathrm{cm}^{2}$, $7.57 \pm 0.68 \mathrm{Kg} / \mathrm{cm}^{2}$ respectively were in the Sudanese, Indian and Europe standards for leather quality of $45 \%, 200 \mathrm{Kg} / \mathrm{cm}^{2}$, $7.0 \mathrm{Kg} / \mathrm{cm}^{2}$ and $8.0 \mathrm{Kg} / \mathrm{cm}^{2}$ for the mentioned characteristics respectively. Whilst flexibility parameter was below the Sudanese standard threshold specification for cattle leather quality [18] found that, flexibility parameter for Arabi camel was $59.3 \pm 3.77 \%$ and blew the Sudanese, Indian, and European standards for leather quality of $100 \%$ for the mentioned characteristic (Table 3).

\section{Western Sudan Arabi camel leather chemical quality pa- rameters}

Significant differences $(\mathrm{P} \leq 0.05)$ were detected among moisture and chrome oxide content values respectively. But no significant differences $(\mathrm{P} \leq 0.05)$ were observed among Ash and fat contents values respectively. Chemical quality parameters were in the Sudanese standards threshold specification for cattle leather quality of $18 \%, 4.5 \%, 2.5 \%$, and $11 \%$ for moisture, Ash, chrome oxide, and fat contents respectively. These results confirm [18-22] who mentioned that camel leather chemical quality parameters; moisture, Ash, chrome oxide, and fat of $4.61 \pm 0.26 \%, 6.21 \pm 0.30 \%, 3.28 \pm 0.29 \%$, and $9.46 \pm 0.38 \%$ respectively were in the Sudanese, Indian and Europe standards for leather quality of $18 \%, 4.5 \%, 2.5 \%$ and $11 \%$ for the mentioned characteristics respectively (Table 4 ).

Table 3: Western Sudan Arabi camel leather physical quality.

\begin{tabular}{|c|c|c|c|c|}
\hline Parameter & Kababish & Meidob & Hawawir & Standard \\
\hline Elongation\% & $44.73 \pm 2.2^{\mathrm{a}}$ & $33.22 \pm 6.5^{\mathrm{b}}$ & $31.60 \pm 7.8^{b}$ & Maximum $45 \%$ \\
\hline Tensile strength $\mathrm{Kg} / \mathrm{cm}^{2}$ & $225 \pm 6.5^{\mathrm{a}}$ & $208 \pm 5.3^{b}$ & $209 \pm 3.6^{b}$ & Minimum $200 \mathrm{~kg} / \mathrm{cm}^{2}$ \\
\hline $\begin{array}{l}\text { Resistance to grain } \\
\text { cracking } \mathrm{N} / \mathrm{cm}^{2}\end{array}$ & $6.46 \pm 0.6^{a}$ & $6.84 \pm 0.8^{a}$ & $6.74 \pm 0.8^{\mathrm{a}}$ & Minimum 7.0 N/cm \\
\hline Breaking load N/cm² & $9.84 \pm 0.55^{\mathrm{a}}$ & $7.84 \pm 0.42^{b}$ & $8.03 \pm 0.5^{b}$ & $\begin{array}{l}\text { Minimum } 8.0 \\
\qquad \mathrm{~N} / \mathrm{cm}\end{array}$ \\
\hline Tear strength $\mathrm{Kg} / \mathrm{cm}^{2}$ & $95.54 \pm 7.1^{\mathrm{a}}$ & $90.92 \pm 6.5^{\mathrm{a}}$ & $93.56 \pm 5.3^{\mathrm{a}}$ & Minimum $100 \mathrm{~kg} / \mathrm{cm}^{2}$ \\
\hline Flexibility\% & $87.20 \pm 3.93^{\mathrm{a}}$ & $65.30 \pm 2.7^{b}$ & $63.40 \pm 2.6^{b}$ & Minimum $100 \%$ \\
\hline \multicolumn{5}{|c|}{$\begin{array}{l}\text { Values in the same row with the same superscripts do not significantly differ at } \\
0.05\end{array}$} \\
\hline \multicolumn{5}{|c|}{ Standards: Sudanesestandards (SSMO 8,9, 18, 19,20). } \\
\hline
\end{tabular}

Table 4: Western Sudan Arabi camel leather chemical quality

\begin{tabular}{|c|c|c|c|c|}
\hline Parameter & Kababish & Meidob & Hawawir & Standard \\
\hline Moisture\% & $8.40 \pm 0.3^{\mathrm{b}}$ & $9.75 \pm 0.6^{\mathrm{b}}$ & $11.66 \pm 0.4^{\mathrm{a}}$ & Maximum 18\% \\
\hline Ash\% & $6.20 \pm 0.3^{\mathrm{a}}$ & $6.27 \pm 0.8^{\mathrm{a}}$ & $6.34 \pm 0.2^{\mathrm{a}}$ & Minimum 4.5\% \\
\hline Fat\% & $9.40 \pm 0.5^{\mathrm{a}}$ & $9.38 \pm 0.3^{\mathrm{a}}$ & $9.58 \pm 0.7^{\mathrm{a}}$ & Maximum 11\% \\
\hline chrome oxide\% & $3.88 \pm 0.5^{\mathrm{a}}$ & $3.53 \pm 0.5^{\mathrm{b}}$ & $3.23 \pm 0.4^{\mathrm{b}}$ & Minimum 2.5\% \\
\hline
\end{tabular}

Values in the same row with the same superscripts do not significantly differ at 0.05

Standard: Sudanese standards (SSMO 11,12,13,21).

\section{Conclusion}

Camel leather is similar in it is quality to cattle leather. Therefore camel leather is suitable for manufacturing all types of leather articles those cattle leathers are used for. But with less quality in flexibility which will reflect in the less expected lifetime of camel leather articles in comparison to cattle leather articles.

\section{References}

1. Ishag I (2009) Production system, Phenotypic and Molecular Characterization of Sudanese Camels (Camelus dromedarius). PhDThesis. Department of Genetics and animal Breeding, Faculty of Animal production, University of Khartoum- Khartoum, Sudan. Link: https://bit.ly/3o6AF9R

2. Wardeh MF (2004) Classification of the Dromedary Camels. J Camel Sci 1 1-7. Link: https://bit.ly/3FZpHZT

3. Kadim IT, Mahgoub O, Mbaga M (2014) Potential of camel meat as a nontraditional high quality source of protein for human consumption. Animal Frontiers 4: 13-17. Link: https://bit.ly/3litkT2

4. Gihad EA (1995) Arabian camels, production and culture. Department of Animal production, Faculty of agriculture, Cairo University, Arab publishing and distributing company.

5. Kalafalla Al (1999) Camel Breeds in the Sudan. Albuhuth J. Sci National Center for Research 8. Part (1). Forth Scientific Conference.

6. Abbas BN, Chadeuf G, Saint-Martin P, Bonnet A, Millaird H, et al. (1992) Camel pastoralism in the butana and North Eastern Sudan: an interdisciplinary study Nomadic person 31: 66-84. Link: https://bit.ly/3lhT8bR

7. Hashim WM, Galal MY, Ali AM, Kalafalla Al, Hamid SA, et al. (2015) Dromedary camels in sudan, types and sub types, distribution and movement. International Journal of Pharmaceutical Research \& Analysis 5: 8-12. Link: https://bit.ly/3o4ZwuG

8. Ebrahiem MA (2015a) Leather Quality of Sudan Desert Sheep goats. Lambert Academic Publishing, Germany Link: https://bit.ly/3pgy4tc

9. SSMO5-Sudanese Standard and Metrology Organization (2003) Leather standards: leather physical tests- Tensile Strength. Khartoum, Sudan.

10. SSMO6-Sudanese Standard and Metrology Organization (2001) Leather standards: physical tests for upper leather- Khartoum, Sudan.

11. SLTC -Society of Leather Trades Chemists (2015) Official methods of analysis. Fourth revised edition- Society of leather trades chemists 52 crouch hall line, Redbourn, Herts.

12. SSMO1 -Sudanese Standard and Metrology Organization (2006) Leather standards: determination of moisture in leather- Khartoum, Sudan.

13. SSMO2 -Sudanese Standard and Metrology Organization (2006) Leather standards: determination of Ash in leather- Khartoum, Sudan.

Citation: Ebrahiem MA, Idris IA (2021) Western Sudan Arabi camel hides attributes and leather quality characteristics. Open J Environ Biol 6(1): 040-043. 
14. SSMO3 -Sudanese Standard and Metrology Organization (2006) Leather standards: determination of chrome oxide in leather- Khartoum, Sudan.

15. SPSS (1996) Statistical Packages for the SocialSciences. Cary, North Carolina.

16. Ebrahiem MA, Ali MA, Turki I, Haroun HE, Bushara I, et al. (2015b) Defects and Grading of Hides and Skins in Kordofan Region, Sudan. Lambert Academic Publishing, Germany. Link: https://bit.ly/3d1bn6D

17. Teklebrhan T, Urge M, MekashaY (2012) Skin/leather quality of indigenous and crossbred (Dorper $x$ Indigenous) F1 sheep. Haramaya University, School of Animal and Range Sciences, P.O Box 138, Dire Dawa, Ethiopia. Link: https://bit.ly/3o5zuHG

18. Ahamed HA, Hamed A, Alhadi M, Ebrahiem MA (2021) Evaluation of Sudanese Arabi Camel Hides for Leathers Manufacturing. EC veterinary Scinece 10: 1331. Link: https://bit.ly/32Q4Ji5
19. SSMO7 -Sudanese Standard and Metrology Organization (2004) Leather Standards: for garment leather- Khartoum, Sudan.

20. SSM08-Sudanese Standard and Metrology Organization (2008) Leather metrology: for lining leather - Khartoum, Sudan.

21. SSMO9 -Sudanese Standard and Metrology Organization (2008) Leather Standards: for shoe upper vegetable and chrome tanned leather-Khartoum, Sudan.

22. SSMO4 -Sudanese Standard and Metrology Organization (2006) Leather standards: determination of fats and oils in leather- Khartoum, Sudan.
Discover a bigger Impact and Visibility of your article publication with Peertechz Publications

\section{Highlights}

* Signatory publisher of ORCID

* Signatory Publisher of DORA (San Francisco Declaration on Research Assessment)

* Articles archived in worlds' renowned service providers such as Portico, CNKI, AGRIS, TDNet, Base (Bielefeld University Library), CrossRef, Scilit, J-Gate etc.

* Journals indexed in ICMJE, SHERPA/ROMEO, Google Scholar etc.

* OAI-PMH (Open Archives Initiative Protocol for Metadata Harvesting)

* Dedicated Editorial Board for every journal

* Accurate and rapid peer-review process

* Increased citations of published articles through promotions

* Reduced timeline for article publication

Submit your articles and experience a new surge in publication services (https://www.peertechz.com/submission).

Peertechz journals wishes everlasting success in your every endeavours. 